\title{
The New Social Question
}

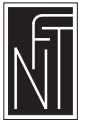





\section{Pierre Rosanvallon}

\section{The New Social Question}

RETHINKING THE WELFARE STATE

Translated by Barbara Harshav

With a Foreword by Nathan Glazer

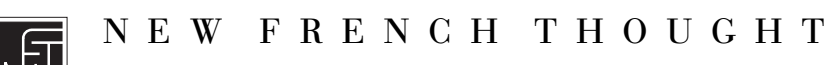


Copyright (C) 2000 by Princeton University Press

Published by Princeton University Press, 4I William Street,

Princeton, New Jersey 08540

In the United Kingdom: Princeton University Press, Chichester, West Sussex

Translated from the French edition of Pierre Rosanvallon's La nouvelle question sociale: Repenser l'Etat-providence (Paris: Seuil, 1995)

All Rigits Reserved

Library of Congress Cataloging-in-Publication Data

Rosanvallon, Pierre, I948- .

[Nouvelle question sociale. English]

The new social question : rethinking the welfare state / Pierre Rosanvallon ; translated by Barbara Harshav ; with a foreword by Nathan Glazer.

p. cm. - (New French thought)

Includes bibliographical references and index.

ISBN 0-69I-oI640-2 (cloth : alk. paper)

I. Welfare state. 2. France-Economic policy. 3. France-Social policy.

I. Title. II. Series

HC276.R6513 2000

$3^{306} .0944-\mathrm{dc} 21 \quad 99-037483$

Published with the assistance of the French Ministry of Culture.

This book has been composed in Adobe Bauer Bodoni

The paper used in this publication meets the minimum requirements of ANSI/NTSO Z39.48-I992 (R 1997) (Permanence of Paper)

http://pup.princeton.edu

Printed in the United States of America

I0 $9 \begin{array}{llllllll} & 8 & 7 & 6 & 4 & 3 & 2 & \text { I }\end{array}$ 